\title{
Induced Resistance by a Long-Chain Bacterial Volatile: Elicitation of Plant Systemic Defense by a C13 Volatile Produced by Paenibacillus polymyxa
}

\author{
Boyoung Lee ${ }^{1,2}$, Mohamed A. Farag ${ }^{3}$, Hyo Bee Park ${ }^{1}$, Joseph W. Kloepper ${ }^{4}$, Soo Hyun Lee', Choong- \\ Min Ryu ${ }^{1,2 *}$
}

1 Molecular Phytobacteriology Laboratory, Systems and Synthetic Biology Research Center, KRIBB, Daejeon, South Korea, 2 Biosystems and Bioengineering Program, University of Science and Technology, Daejeon, South Korea, 3 Pharmacognosy Department, Faculty of Pharmacy, Cairo University, Cairo, Egypt, 4 Department of Entomology and Plant Pathology, Auburn University, Auburn, Alabama, United States of America

\begin{abstract}
Background: Some strains of plant growth-promoting rhizobacteria (PGPR) elicit induced systemic resistance (ISR) by emission of volatile organic compounds (VOCs) including short chain alcohols, acetoin, and 2,3-butanediol. The objective of this study was to evaluate whether species-specific VOCs from PGPR strain Paenibacillus polymyxa E681 can promote growth and induce resistance in Arabidopsis.

Methodology/Principal Findings: The efficacy of induction was strain-specific, with stronger protection against Pseudomonas syringae pv. maculicola ES4326 in plants exposed to VOCs from P. polymyxa E681 versus Arabidopsis plants exposed to VOCs from a reference strain Bacillus subtilis GB03, which was previously shown to elicit ISR and plant growth promotion. VOC emissions released from E681 primed transcriptional expression of the salicylic acid, jasmonic acid, and ethylene signaling marker genes $P R 1, C h i B$, and VSP2, respectively. In addition, strain E681 produced more than thirty low molecular-weight VOCs, of which tridecane was only produced by E681 and not found in GB03 or IN937a volatile blends. These strain-specific VOCs induced PR1 and VSP2 genes.

Conclusions/Significance: These results provide new insight into the existence of a long chain VOC signaling molecule produced by $P$. polymyxa that can serve as a bacterial trigger of induced systemic resistance in planta.
\end{abstract}

Citation: Lee B, Farag MA, Park HB, Kloepper JW, Lee SH, et al. (2012) Induced Resistance by a Long-Chain Bacterial Volatile: Elicitation of Plant Systemic Defense by a C13 Volatile Produced by Paenibacillus polymyxa. PLoS ONE 7(11): e48744. doi:10.1371/journal.pone.0048744

Editor: Boris Alexander Vinatzer, Virginia Tech, United States of America

Received February 10, 2012; Accepted October 1, 2012; Published November 28, 2012

Copyright: (C) 2012 Lee et al. This is an open-access article distributed under the terms of the Creative Commons Attribution License, which permits unrestricted use, distribution, and reproduction in any medium, provided the original author and source are credited.

Funding: Financial support that was obtained from the Basic Science Research Program through the National Research Foundation of Korea (NRF) funded by the Ministry of Education, Science and Technology (2010-0011655), the Industrial Source Technology Development Program of the Ministry of Knowledge Economy (TGC0281011) of Korea, the Next-Generation BioGreen 21 Program (SSAC grant \#PJ008170), Rural Development Administration, and the KRIBB initiative program, South Korea is gratefully acknowledged. The funders had no role in study design, data collection and analysis, decision to publish, or preparation of the manuscript.

Competing Interests: The authors have declared that no competing interests exist.

*E-mail: cmryu@kribb.re.kr

\section{Introduction}

Plant growth-promoting rhizobacteria (PGPR) are a group of root-colonizing bacteria in the rhizosphere of many plant species that enhance plant productivity and often elicit plant immunity against multiple plant pathogens [1,2,3], a process referred to as induced systemic resistance (ISR). PGPR have been found to produce many bacterial determinants that promote plant growth and reduce disease $[4,5]$. Reduced disease can be via antibiotics and other bacterial metabolites that directly impact pathogens $[6,7]$. Bacterial cell surface compounds and secreted compounds that have been identified as bacterial determinants responsible for ISR $[1,2,3,8]$ are lipopolysaccharides, salicylic acid (SA), 2,4diacetylphloroglucinol, and siderophores.

In 2003, volatile organic compounds (VOCs) emitted by two Bacillus spp. were shown to be novel determinants of both plant growth promotion and elicitation of ISR in Arabidopsis $[7,9,10]$. Ryu et al. (2003) demonstrated significant growth promotion of
Arabidopsis by Bacillus subtilis strain GB03 and B. amyloliquefaciens strain IN937a [10]. Among VOCs released from strain GB03, 2,3butanediol was found as a major component that promoted plant growth and elicited ISR against Erwinia carotovora subsp. carotovora. Several mutant lines of Arabidopsis, including brassinosteroid- and gibberellic acid-insensitive mutants, auxin-transport-deficient mutants, and cytokinin receptor-deficient mutants, were used to elucidate the signaling pathways that promote growth [10]. The VOCs tested did not promote plant growth in $\mathrm{cre} 1$, a cytokinin receptor-deficient mutant, suggesting that cytokinin signaling is essential for the promotion of plant growth in response to bacterial volatiles [10].

Further, a study using Affymetrix Arabidopsis AG GeneChip revealed that volatile emissions from strain GB03 differentially upregulated more than 600 transcripts, which encoded proteins with various functions such as cell wall modification, primary and secondary metabolism, stress responses, and hormone regulation [11]. Exposure of Arabidopsis to VOCs from strains GB03 and 
IN937a also resulted in a significant reduction in disease severity caused by E. carotovora subsp. carotovora via an ethylene (ET)dependent but salicylic acid -independent signaling pathway [9]. Using the PR1 as an indicator gene for SA signaling, researchers found no role for SA signaling during ISR elicited by volatiles from strain GB03.

PGPR strain E681 was isolated from roots of winter barley (Hordeum vulgare L.) in southern Korea and identified as a potential biological control agent that could promote growth and elicit biological control activity in diverse crop systems. Seed treatment with E681 was found to suppress early seedling damping-off in cucumber (Cucumis sativus L.) and sesame (Sesamum indicum L.). It also increased biological control capacity in greenhouse for cucumber and the field for sesame $[3,12,13]$. From in vitro testing to field trials, strain E681 has been identified as an agent that can elicit biological control as well as increase grain yield [3]. One possible explanation for the promotion of growth by strain E681 is via production of plant growth regulators auxin and cytokinin $[14,15,16]$. Whole genome sequencing of strain E681 revealed that it encodes an entire set of genes related to the production of indole acetic acid (IAA) [17].

Previously, it was problematic to test hemibiotrophic pathogenic bacteria such as $P$. syringae pv. maculicola ES4326 on Arabidopsis grown under in vitro conditions considering that drop-inoculation cannot easily elicit typical symptoms. To determine the bacterial volatile-mediated ISR capacity of E681 against a semibiotrophic bacterial pathogen $P$. syringae, a method of dipping seedlings into a suspension of pathogenic bacteria was developed. A bioassay system using tightly closed I-plates was previously used to assess the effects of volatiles on plant growth and ISR $[9,10]$. The overall objective of this study was to determine if species-specific VOCs from $P$. polymyxa strain E681 promote plant growth and induce resistance against $P$. syringae pv. maculicola ES4326 in Arabidopsis. Using hormonal mutant lines of Arabidopsis, we further elucidated a plant hormone signaling pathway responsible for growth promotion. Comparison of bacilli VOG profiles from strains GB03, IN937a, and E681 revealed that tridecane, a C13 hydrocarbon produced exclusively by strain E681 and not from other tested bacilli spp., was a bacterial determinant that played a novel role in meditating ISR by priming defense genes such as PR1, VSP2, and ChiB.

\section{Results}

\section{Enhancement of Arabidopsis growth by Paenibacillus polymyxa E681 volatiles}

$P$. polymyxa E681 elicited the most growth promotion of Arabidopsis in the microtitre plate assay when the plant was located $2 \mathrm{~cm}$ from the bacteria (Figs. 1A and 1B). At this distance, total leaf surface area was increased $60 \%$ by strain E681 compared to control plants exposed to water. The total leaf surface area of Arabidopsis seedlings also increased following exposure to VOCs released from strains E681 and GB03 at all distances from the bacterial inoculation site. However, with strain GB03, growth of Arabidopsis seedlings placed $2 \mathrm{~cm}$ away from the bacteria increased more than seedlings grown at distances of $4,6,8$, and $10 \mathrm{~cm}$. This finding could be explained by the slow dispersal of the bacterial volatiles due to the lid being tightly closed. Another explanation could be that an insufficient concentration of VOCs delayed their ability to reach and affect plants grown further from the inoculation site.

To elucidate the mechanism underlying the observed plant growth promotion by bacterial VOCs, a series of mutant and transgenic Arabidopsis lines were assessed for responses to VOCs released by strains E681 and GB03. Results demonstrated differential plant growth promotion among various Arabidopsis lines. For example, plant growth was significantly enhanced by VOCs released from both bacterial strains in three Arabidopsis lines: coronatine/jasmonic acid (JA)-insensitive line, coil, a SA-degrading line, NahG, and a gibberellic acid-insensitive line, gai2 (Fig. 1C). In contrast, bacterial VOCs did not enhance growth of the ET- and cytokinin-insensitive Arabidopsis line, ein2.5, indicating growth promotion elicited by bacterial volatiles is mediated by the ET and or cytokinin signaling pathways (Fig. 1C).

\section{Elicitation of induced systemic resistance by bacterial volatiles in the microtitre system}

As described in Materials and Methods, a new pathogenicity assay was developed, which was compatible with the microtitre plate system, using the foliar pathogen Pseudomonas syringae pv. maculicola ES4326 (P. s. maculicola). Soaking of Arabidopsis seedlings in a suspension of $P$. s. maculicola resulted in severe chlorosis at five days after inoculation and necrosis by seven days after inoculation (Fig. 2). The severity of disease was reduced two weeks after exposure of Arabidopsis seedlings to bacterial volatiles from strain E681 placed 2, 4, and $6 \mathrm{~cm}$ away from the seedlings in the microtitre system (Fig. 2). The maximum level of disease protection in this test occurred when Arabidopsis seedlings were placed $2 \mathrm{~cm}$ away from strain E681. VOCs released from PGPR strains E681 and GB03 also significantly reduced the disease severity from $P$. s. maculicola irrespective of distance from the PGPR inoculation site. The disease severity in Arabidopsis seedlings grown $10 \mathrm{~cm}$ away from E681 and GB03 did not differ relative to control treatment.

\section{Profiling of volatiles released by Paenibacillus polymyxa E681}

Solid-phase micro extraction (SPME) coupled with gas chromatography-mass spectrometry (GC-MS) was previously reported to be useful for profiling volatiles from PGPR strains [18]. Results from this analysis [18] provided a comprehensive compositional profile of VOCs released by strain IN937a and GB03. Therefore, it was used in the current study for profiling volatiles of strain E681. High levels of acetoin were consistently released from strains E681, IN937a, and GB03 (74, 153, and $226 \mu \mathrm{g} / 24 \mathrm{~h}$, respectively), while the negative control strain $89 \mathrm{~B} 61$ released only $0.1 \mu \mathrm{g} /$ $24 \mathrm{~h}$ (Table 1). Marginal detection levels of 2,3-butanediol were found in VOCs released by E681. Other volatiles released from the three bacilli strains GB03, IN937a, and E681 included methanethiol, isoprene, and acetic acid-butyl ester (Table 1). A comparison of the VOC profiles of strains GB03, IN937a, and E681 revealed that tridecane, a C13 hydrocarbon (MW $=184.35$ daltons; Fig. 3B inset), was released exclusively from strain E681 (Table 1).

It should be noted that enhanced growth promotion is unlikely to be mediated by $\mathrm{CO}_{2}$ emission levels (Table 1) from bacteria. Comparable $\mathrm{CO}_{2}$ emission levels were observed from $E$. coli DH5 $\alpha(1277 \mu \mathrm{g} / 24 \mathrm{~h})$ and active PGPR strain IN937a $(1912 \mu \mathrm{g} /$ $24 \mathrm{~h}$ ) [18]. Indeed, E681 released $\mathrm{CO}_{2}$ at emission levels almost similar to those released from the inactive E. coli DH5 $\alpha$ [18]. Additional evidence that $\mathrm{CO}_{2}$ does not promote plant growth was observed from plants grown in the presence of $\mathrm{Ba}(\mathrm{OH})_{2}$, which captured released $\mathrm{CO}_{2}$ [19]. Additional evidence for a lack of a role of $\mathrm{CO}_{2}$ in growth promotion was found when the volatiles of strain E681 were found to still promote plant growth when exposed to $\mathrm{Ba}(\mathrm{OH})_{2}$ which captures $\mathrm{CO}_{2}$ (Fig. 3A). The difference in growth between with and without $\mathrm{Ba}(\mathrm{OH})_{2}$ treatments may be 


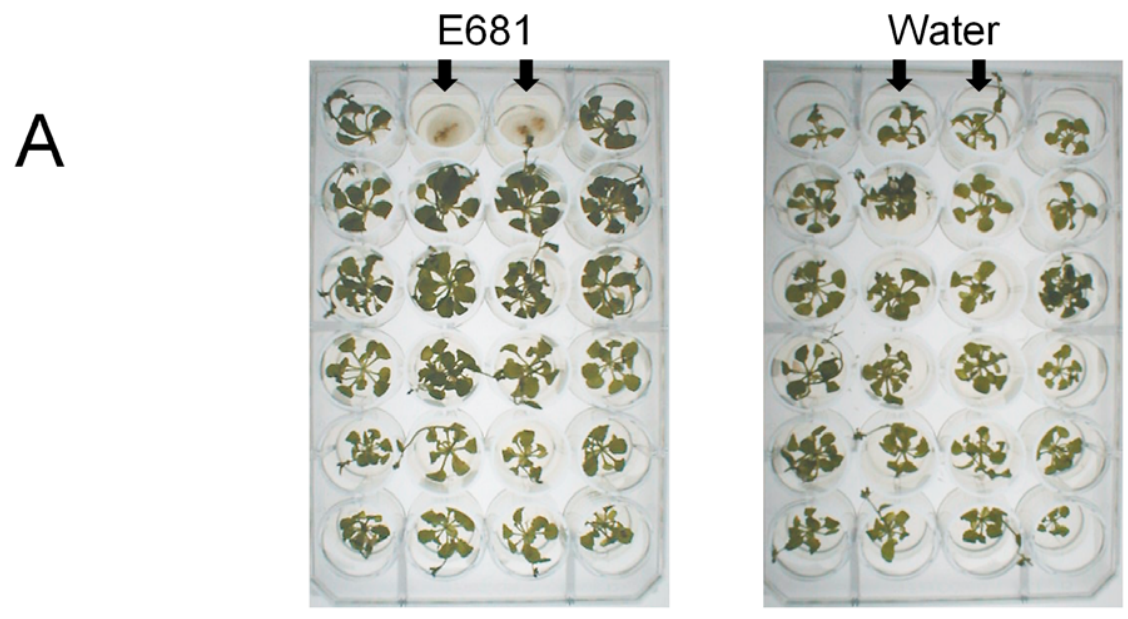

$\mathrm{B}$
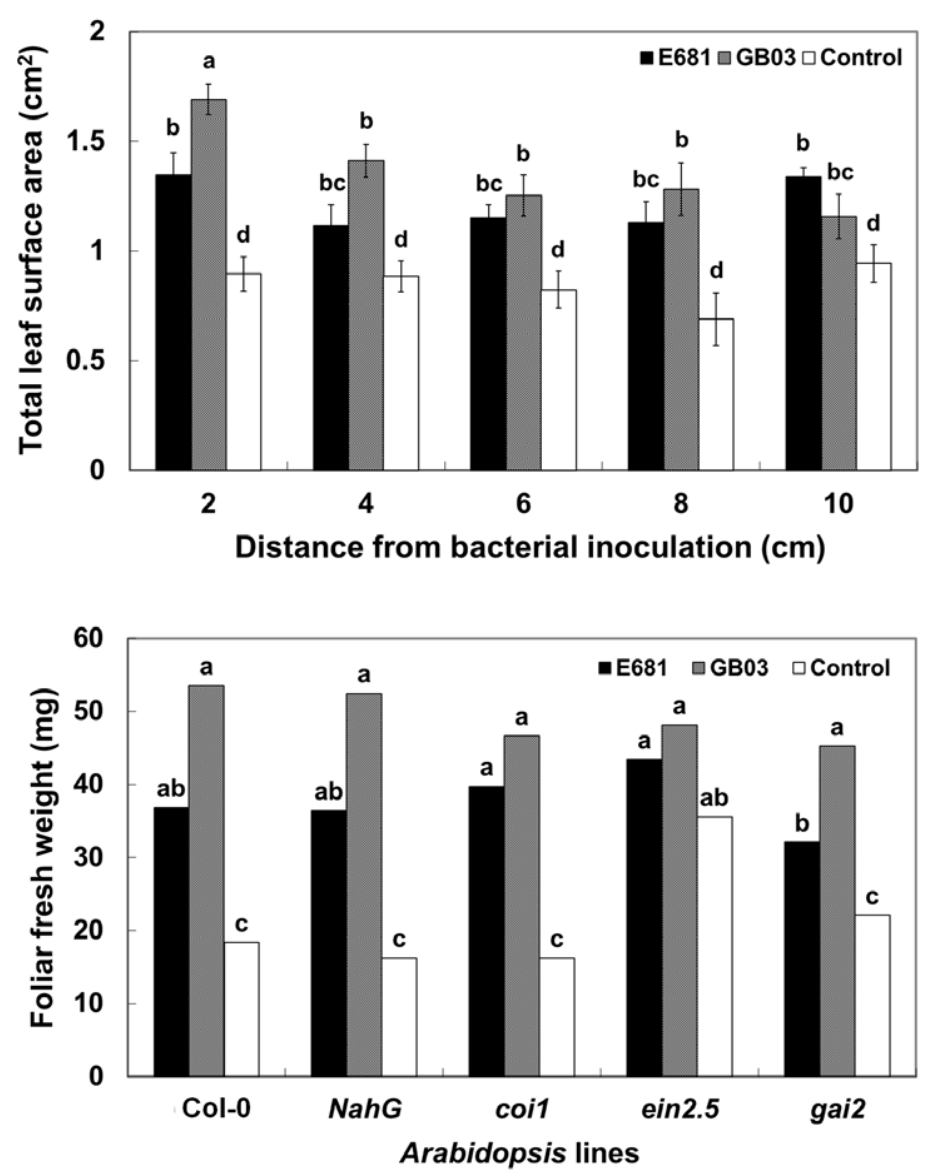

Figure 1. Growth promotion of Arabidopsis seedling by VOCs emitted from Paenibacillus polymyxa E681. A) Illustration of plant growth promotion by VOCs produced by strain E681 in a 24-well microtitre system. The diameter of each well was $2 \mathrm{~cm}$. The photograph was taken two weeks after inoculation with strain E681. Right plate = water control; Left plate $=\mathrm{E} 681$ treatment. The single arrows indicate inoculation site with strain E681 and water control. B) Plant growth at two weeks after exposure to VOCs released by P. polymyxa E681, Bacillus subtilis GB03, and water control in a microtitre system, as indicated by the differences in the total leaf surface areas. C) Plant growth at two weeks after exposure to VOCs released by P. polymyxa E681, Bacillus subtilis GB03, and water control in a microtitre system, as indicated by the differences in the foliar fresh weight in wild type Col-0 and its hormonal mutant lines, transgenic NahG (encodes salicylate hydroxylase and degrades salicylic acid (SA)), ein2.5 (ETinsensitive), coi1 (insensitive to jasmonic acid), and gai2 (insensitive to gibberellic acid). Different letters indicate significant differences between treatments at 2, 4, and $6 \mathrm{~cm}$ away from bacteria inoculation in the microtitre system, according to least significant difference at $P=0.05$. doi:10.1371/journal.pone.0048744.g001 


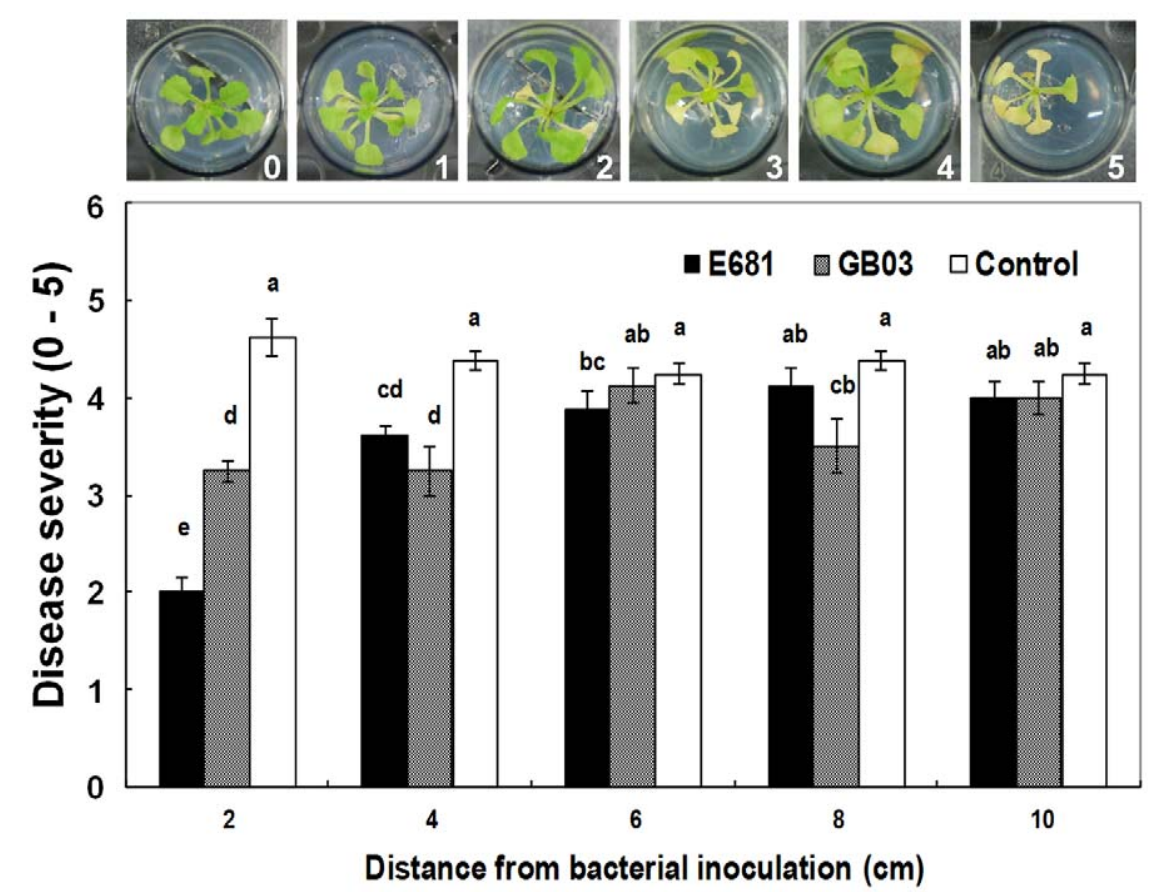

Figure 2. Induction of resistance against Pseudomonas syringae pv. maculicola ES4326 in Arabidopsis exposed to bacterial VOCs. Induced systemic resistance against $P$. syringae pv. maculicola ES4326 elicited by VOCs of $P$. polymyxa E681 and a water control, using the microtitre system. Disease severity $(0=$ no symptom, $10=$ severe chlorosis) was recorded seven days after pathogen challenge. Different letters indicate significant differences between treatments, according to least significant difference at $P=0.05$. The error bars indicate SEM. doi:10.1371/journal.pone.0048744.g002

caused by elimination of total $\mathrm{CO}_{2}$ produced from tested plants and or from strain E681.

\section{Tridecane-elicited induction of systemic resistance against $P$. syringae}

The application of tridecane at $10 \mathrm{mM}$ and $100 \mu \mathrm{M}$ elicited ISR and protected Arabidopsis seedlings against the biotrophic pathogenic bacterium $P$. s. maculicola at seven days after soakinginoculation (Fig. 3). To determine if the dose of tridecane applied in this test was comparable to that released naturally from PGPR strain E681, quantification of tridecane levels in E681 headspace was attempted from small closed vials $20 \mathrm{~mL}$ (see Materials and Methods). The concentration of tridecane released from E681 in the $20 \mathrm{~mL}$ vial headspace reached $3.80 \mu \mathrm{M}$ as determined using the SPME technique and tridecane standard doses analyzed under the same conditions (Table 1). The estimated concentration of introduced volatiles in this experiment reached ca.5.09 $\mu \mathrm{M}$ when the applied $30 \mu \mathrm{l}$ of $10 \mathrm{mM}$ tridecane was fully volatilized and had filled out the estimated volume of a Petri-dish $(100 \mathrm{~mm}$ diameter $\times 15 \mathrm{~mm}$ height). By comparison, the concentration of the introduced tridecane inside a Petri-dish was 1.34 times higher than that detected using SPME from strain E681 (Table 1). Therefore, it is highly like that tridecane application failed to inhibit bacterial growth, which would rule out a direct bacteriostatic effect (data not shown).

\section{Evaluation of tridecane on growth and priming plant defense gene expression}

Volatile emissions from strain E681 promoted plant growth regardless of $\mathrm{Ba}(\mathrm{OH})_{2}$ treatment, whereas $10 \mathrm{mM}$ and $100 \mu \mathrm{M}$ tridecane decreased plant growth without $\mathrm{Ba}(\mathrm{OH})_{2}$ treatment and had no effect on plant growth with the presence of $\mathrm{Ba}(\mathrm{OH})_{2}$ compared to control (Fig. 3A). Interestingly, $10 \mathrm{mM}$ dose of tridecane elicited plant protection at a level similar to that of $100 \mu \mathrm{M}$ tridecane, suggesting that the ISR capacity against $P$. s. maculicola was not affected by difference in concentration levels (Fig. 3B). It is noteworthy that plants exposed to tridecane showed reduced fresh weight compared to the control, negating any role for tridecane in growth promotion.

To test for the induction of three defense genes, PR1 for SA signaling, VSP2 for JA signaling, and ChiB for ET signaling [20], qRT-PCR was conducted at 0 and $6 \mathrm{~h}$ after treatment with strain E681 and tridecane and at 0 and $3 \mathrm{~h}$ following challenge inoculation with bacterial pathogen $P$. s. maculicola challenge. Indirect (volatile) application of tridecane in I-plates did not significantly alter expression of PR1, VSP2, or ChiB (Figs. 3C, D and $\mathrm{E}$ ). To evaluate defense priming of the 3 marker genes, gene expression levels were measured at $3 \mathrm{~h}$ following pathogen challenge. Arabidopsis was primed by PR1, VSP2, and ChiB gene expression through exposure to strain E681 volatile emissions, suggesting that SA, JA, and ET dependent signaling pathways were induced (Figs. 3F, G and $\mathrm{H}$ ). Moreover, $10 \mathrm{mM}$ tridecane resulted in a 4.7 -fold increase in transcription of $P R 1$ compared to the water control before pathogen challenge (Fig. 3C) and 3.3-fold increase at $3 \mathrm{~h}$ after pathogen challenge (Fig. 3F). Similar results were observed for PR1 gene in plants exposed to VOCs from strain E681 (Fig. 3F). At $10 \mathrm{mM}$, tridecane increased VSP2 gene expression 2.5 fold compared to the control, albeit $100 \mu \mathrm{M}$ tridecane showed no such effect on PR1, VSP2, and ChiB transcript levels (Figs. 3C to H). In summary, VOCs from PGPR strain E681 primed three defense genes - PR1, VSP2, and ChiB - which correspond to the elicitation of SA, JA, and ET signaling pathways. However, tridecane only induced PR1 and VSP2 after pathogen challenge. Tridecane at 10 and $100 \mu \mathrm{M}$ did not lead to plant growth promotion but rather elicited ISR, suggesting that 
Table 1. Volatile profile of Bacillus amyloliqefaciens IN937a, B. subtilis GB03, and Paenibacillus polymyxa E681 using solid-phase micro extraction combined with gas chromatography-mass spectrometry.

\begin{tabular}{|c|c|c|c|c|}
\hline \multirow{2}{*}{ RT (min) } & \multirow{2}{*}{ Compounds ${ }^{a}$} & \multicolumn{3}{|c|}{ VOC contents from PGPR strains (a.u. or $\mu \mathrm{g})^{\mathrm{bcd}}$} \\
\hline & & B. amyloliquefaciens & B. subtilis & P. polymyxa \\
\hline \multicolumn{5}{|l|}{ Acohol } \\
\hline 4.49 & Ethanol *\$ & $10 \pm 3 \mathrm{~A}$ & $7 \pm 2 A$ & $2 \pm 0.3 \mathrm{BC}$ \\
\hline 6.36 & 1-propanol-2-methyl *\$ & $29 \pm 3 \mathrm{~A}$ & $62 \pm 7 \mathrm{~A}$ & $6 \pm 1.5 \mathrm{~B}$ \\
\hline 7.13 & 1 -Butanol *\$ & $3.6 \pm 0.6 \mathrm{~A}$ & $3.4 \pm 0.3 \mathrm{~A}$ & $0.5 \pm 0.04 \mathrm{~B}$ \\
\hline 8.49 & $1-$ Pentanol $* \$$ & $66 \pm 3 A$ & $0.4 \pm 0.04 \mathrm{~B}$ & ND \\
\hline 8.56 & 1-Butanol-3-methyl *\$ & $3961 \pm 214 A$ & $29 \pm 1 B$ & $19 \pm 1.5 B$ \\
\hline 8.61 & 1-Butanol-2-methyl & $290 \pm 28 \mathrm{~A}$ & $8 \pm 3 B$ & $0.9 \pm 0.07 \mathrm{~B}$ \\
\hline 9.64 & 2,3-Butanediol *\$ & $119 \pm 40 \mathrm{~A}$ & $257 \pm 138 \mathrm{~A}$ & $12 \pm 4 B$ \\
\hline \multicolumn{5}{|l|}{ Aldehydes } \\
\hline 6.87 & Butanal-3-methyl & $29 \pm 3 A$ & $77 \pm 5 B$ & $15 \pm 1 C$ \\
\hline 7.04 & Butanal-2-methyl *\$ & $0.3 \pm 0.03 \mathrm{~A}$ & $0.06 \pm 0.01 \mathrm{~A}$ & ND \\
\hline 12.37 & 2,4-Hexadienal & TR & TR & $0.01 \pm 0.02$ \\
\hline 13.45 & Benzaldehyde $* \$$ & $0.003 \pm 0.04 \mathrm{~A}$ & $0.002 \pm 0.0003 \mathrm{~A}$ & ND \\
\hline \multicolumn{5}{|l|}{ Acids } \\
\hline 9.74 & Glyoxylic acid & $1 \pm 0.2 \mathrm{~A}$ & $0.8 \pm 0.2 \mathrm{~A}$ & $0.7 \pm 0.1 \mathrm{~A}$ \\
\hline 10.8 & Acetic acid diethyl & $6 \pm 0.5 \mathrm{~A}$ & $36 \pm 5 B$ & $2 \pm 0.1 \mathrm{~A}$ \\
\hline 11.10 & Butanoic acid-3-methyl $* \$$ & $0.06 \pm 0.03 \mathrm{~A}$ & $0.3 \pm 0.1 \mathrm{~A}$ & $0.1 \pm 0.4 \mathrm{~B}$ \\
\hline \multicolumn{5}{|l|}{ Esters } \\
\hline 6.11 & Ethyl acetate $* \$$ & $21 \pm 3 A B$ & $49 \pm 10 \mathrm{~A}$ & $12 \pm 5 A$ \\
\hline 10.12 & Acetic acid butyl ester $* \$$ & $2.8 \pm 0.2 B$ & $0.1 \pm 0.02 \mathrm{~A}$ & $4 \pm 1.5 \mathrm{C}$ \\
\hline 11.40 & $\begin{array}{l}\text { Butanol-3-methyl-acetate*\$ } \\
127\end{array}$ & $127 \pm 29$ & TR & TR \\
\hline 12.35 & $\begin{array}{l}\text { 2-Butene-1-ol-3-methyl- } \\
\text { acetate }\end{array}$ & $0.15 \pm 0.01 \mathrm{~A}$ & $0.13 \pm 0.04 \mathrm{~A}$ & $0.1 \pm 0.02 \mathrm{~A}$ \\
\hline \multicolumn{5}{|l|}{ Ethers } \\
\hline 6.08 & Furan-2-methyl *\$ & $0.04 \pm 0.001 \mathrm{~A}$ & $0.1 \pm 0.009 \mathrm{~B}$ & TR \\
\hline 7.50 & $\begin{array}{l}\text { Butane-1-methoxy-3-methyl } \\
* \$\end{array}$ & $7530 \pm 512$ & ND & ND \\
\hline 7.60 & Furan-2-ethyl *\$ & $0.03 \pm 0.01$ & ND & ND \\
\hline 8.83 & $\begin{array}{l}\text { Furan-tetrahydro-2,5- } \\
\text { dimethyl }\end{array}$ & $0.2 \pm 0.02$ & $\mathrm{TR}$ & $\mathrm{TR}$ \\
\hline 13.70 & Furan-2-pentyl $* \$$ & $0.0005 \pm 0.0006 \mathrm{~A}$ & $0.0006 \pm 0.0006 \mathrm{~A}$ & $0.0003 \pm 0.0001 \mathrm{~A}$ \\
\hline \multicolumn{5}{|c|}{ Hydrocarbons } \\
\hline 4.86 & Isoprene $* \$$ & $483 \pm 109 A B$ & $614 \pm 62 B$ & $125 \pm 27 \mathrm{~A}$ \\
\hline 7.53 & Acetylene & $9 \pm 0.8 \mathrm{~A}$ & $0.6 \pm 0.1 \mathrm{~B}$ & $0.12 \pm 0.01 C$ \\
\hline 9.78 & Cyclohexane & $0.1 \pm 0.02 \mathrm{~A}$ & $0.2 \pm 0.07 \mathrm{~A}$ & ND \\
\hline 15.42 & 1-Undecene & $0.8 \pm 0.3 \mathrm{~A}$ & $1.2 \pm 0.1 \mathrm{~A}$ & $0.4 \pm 0.06 \mathrm{AB}$ \\
\hline 15.53 & 1-Undecane & $1.5 \pm 0.12 A B$ & $3 \pm 0.2 \mathrm{~A}$ & $0.2 \pm 0.03 B C$ \\
\hline 17.10 & Dodecane & $0.7 \pm 0.05 \mathrm{~A}$ & $0.9 \pm 0.07 \mathrm{~A}$ & $0.15 \pm 0.01 B$ \\
\hline 18.52 & Tridecane & ND & ND & $0.14 \pm 0.01 \mathrm{~A}$ \\
\hline \multicolumn{5}{|l|}{ Ketones } \\
\hline 4.75 & Acetone *\$ & $0.2 \pm 0.03 \mathrm{~A}$ & $0.3 \pm 0.01 \mathrm{~A}$ & $0.5 \pm 0.5 \mathrm{AB}$ \\
\hline 5.74 & 2,3-Butanedione $* \$$ & $38 \pm 4 \mathrm{~A}$ & $77 \pm 8 \mathrm{~A}$ & $14 \pm 3 B$ \\
\hline 5.85 & 2-Butanone *\$ & $24 \pm 4 B$ & $44 \pm 5 A$ & $12 \pm 2 C$ \\
\hline 8.17 & Acetoin $* \$$ & $153 \pm 22 \mathrm{~A}$ & $226 \pm 37 \mathrm{~A}$ & $74 \pm 12 \mathrm{~A}$ \\
\hline 10.16 & 2-hydroxy-3-pentanone $* \$$ & $3.5 \pm 0.6 \mathrm{~A}$ & $3.5 \pm 0.7 \mathrm{~A}$ & $0.04 \pm 0.02 B$ \\
\hline \multicolumn{5}{|c|}{ S-containing compounds } \\
\hline 4.37 & Methanethiol *\$ & $0.6 \pm 0.1 \mathrm{~A}$ & $0.1 \pm 0.01 \mathrm{~A}$ & $0.3 \pm 0.09 \mathrm{~A}$ \\
\hline
\end{tabular}


Table 1. Cont.

\begin{tabular}{|c|c|c|c|c|}
\hline \multirow[t]{2}{*}{ RT (min) } & \multirow[t]{2}{*}{ Compounds $^{a}$} & \multicolumn{3}{|c|}{ VOC contents from PGPR strains (a.u. or $\mu \mathrm{g})^{\text {bcd }}$} \\
\hline & & B. amyloliquefaciens & B. subtilis & P. polymyxa \\
\hline 8.67 & Dimethyl disulfide *\$ & $4 \pm 0.1 \mathrm{~A}$ & $2.4 \pm 0.2 \mathrm{~B}$ & $2 \pm 0.2 \mathrm{BC}$ \\
\hline 13.48 & Dimethyl trisulfide & $0.12 \pm 0.02$ & $0.18 \pm 0.01 \mathrm{~A}$ & $0.1 \pm 0.01 \mathrm{~A}$ \\
\hline \multicolumn{5}{|c|}{ Inorganic compound } \\
\hline 4.03 & Carbon dioxide & $1912 \pm 40 \mathrm{~A}$ & $3907 \pm 150 \mathrm{~B}$ & $1277 \pm 246 \mathrm{~A}$ \\
\hline
\end{tabular}

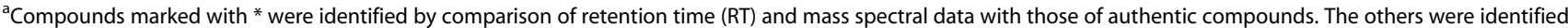
by comparison of mass spectral data with those of NIST library. ${ }^{\mathrm{b}}$ Results are means of triplicate experiments; ND, not detected.

${ }^{c}$ Values for compounds marked with $\$$ are concentrations, expressed in $\mu \mathrm{g} / 24 \mathrm{~h}$. Values unmarked are expressed as relative peak areas to (Z)-3-hexenyl acetate (IS) expressed in arbitrary units (a.u.). The volatile profiling of B. amyloliquefaciens and B. subtilis was adapted from the previous publication [18]. It should be noted that all volatile measurements were acquired at same time and under similar conditions from 3 PGPR.

dValues followed by the same letter within the same row are not significantly different $(P>0.05)$.

doi:10.1371/journal.pone.0048744.t001

other unknown bacterial volatiles from strain E681 play a role in growth promotion.

\section{Induced resistance and defense priming by $\mathrm{C} 10, \mathrm{C} 11$, and C12 bacterial volatiles}

The capacity of other long chain hydrocarbons that differ from tridecane by only one carbon unit, including C10, G11, and C12, to retain elicitation of plant defense against $P$. s. maculicola, was assessed. Accordingly, decane (G10), undecane (G11), and dodecane (G12), each at $10 \mathrm{mM}$ and $100 \mu \mathrm{M}$, were tested in the I-plate system for elicitation of ISR against $P$. s. maculicola. All 3 hydrocarbons significantly decreased disease severity at $10 \mathrm{mM}$ (Fig. 4A). The greatest ISR effects were observed with $100 \mu \mathrm{M}$ decane and $10 \mathrm{mM}$ undecane. These results indicate that some other long chain hydrocarbons can elicit ISR as does tridecane. Gene expression patterns mediating ISR were monitored in response to decane, undecane, and dodecane treatments in order to obtain further molecular evidence that the hydrocarbons mediated ISR. The expression patterns of PR1, ChiB, and VSP2 expression pattern at 0 and $6 \mathrm{~h}$ post inoculation (hpi) were not significantly altered by any of the three hydrocarbons at $10 \mathrm{mM}$ and $100 \mu \mathrm{M}$ (Figs. 4B, C, and D). It should be noted that higher background expression levels of the three defense genes were detected at $0 \mathrm{~h}$ following application of $10 \mathrm{mM}$ and $100 \mu \mathrm{M}$ decane, undecane, and dodecane (Figs. 4B, C, and D). Only treatment with $10 \mathrm{mM}$ undecane showed an increase, which was as high as 4.2- fold on mRNA transcriptional level of PR1 gene compared to control at 3 hpi (Figs. 4E, F, and G).

\section{Discussion}

The results reported here demonstrate for the first time that PGPR strain Paenibacillus polymyxa E681 produces a volatile blend that can enhance plant growth and elicit ISR against $P$. syringae in the absence of physical contact with plants (Fig. 1B). A new VOC assay system, based on a 24-well microtitre plate, was developed for studying the effects of volatiles produced by bacteria in planta (Figs. 1A, B and C). To overcome the difficulty of testing biotrophic bacteria such as $P$. syringae, a new seedling-dip method was developed that resulted in consistent symptom development of bacterial speck caused by $P$. syringae. Using this test system, we found that ISR elicited by VOCis released from strain E681 (Fig. 2) is mediated by priming of the defense genes PR1, ChiB, and VSP2 (Figs. 3B to $\mathrm{H}$ ).
To elucidate signaling pathways involved in growth promotion in response to VOGs, we evaluated Arabidopsis mutant lines that were defective in responding to known volatile signal molecules such as jasmonic acid (methyl jasmonate), ET, and salicylic acid (methyl salicylate). We cannot exclude the possibility that plant growth promotion by bacterial volatiles was in part due to elevated $\mathrm{CO}_{2}$ levels in the closed Petri dish system [19]. However, additional experiments revealed that strain E681 still enhanced plant growth when $\mathrm{CO}_{2}$ was captured with $\mathrm{Ba}(\mathrm{OH})_{2}$, a finding suggesting that $\mathrm{CO}_{2}$ may not be the only factor accounting for growth promotion(Fig. 3B).

An unexpected finding was that the ISR response against $P$. syringae pv. maculicola ES4326 was stronger in plants exposed to VOCs emitted from strain E681 than from strain GB03. In tobacco, 2,3-butanediol elicited ISR against the necrotrophic bacterium Erwinia carotovora subsp. carotovora but not against the biotrophic bacterial pathogen $P$. syringae [21]. This result led us to investigate whether the unique VOC blend released from strain E681 can more effectively elicit ISR response against pathovars of $P$. syringae via the elicitation of SA signaling pathway. To obtain a more detailed understanding of the underlying mechanism, we previously established that VOCs produced by strain GB03 triggered ET-dependent signaling in the exposed plant [9]. Interestingly, VOCs released by strain E681 significantly $(P=0.05)$ increased GUS activity of the promoter of $P R 1$, an indicator of systemic acquired resistance or SA signaling (Figure $\mathrm{S} 1)$.

To our knowledge, the only other bacterial species known to produce tridecane is Pseudomonas aeruginosa [22]. Aside from its production in bacteria, tridecane was also identified as an insect pheromone [23] and defensive signaling molecule by stink bug $[24,25,26]$. To date, microbial production of this hydrocarbon has not been extensively studied, and a plant's response to tridecane has not been assessed. How plants perceive and respond to tridecane has yet to be fully elucidated using large scale gene expression techniques by screening Arabidopsis mutants and transcriptional/proteomic changes by tridecane treatment. It remains to be determined whether tridecane is released in the rhizosphere where PGPR normally reside and whether ISR elicited by VOCs from strain E681 occurs in soil or soil-less media.

Production of cytokinin by $P$. polymyxa, or by plants exposed to $P$. polymyxa, was previously proposed as a bacterial determinant in growth promotion [16]. Our data presented here indicate that bacterial volatiles emitted from $P$. polymyxa E681 play an important role in growth promotion of Arabidopsis seedlings. Moreover, out of 
A

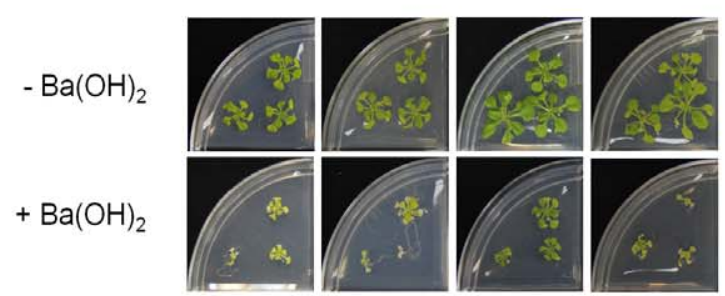

B
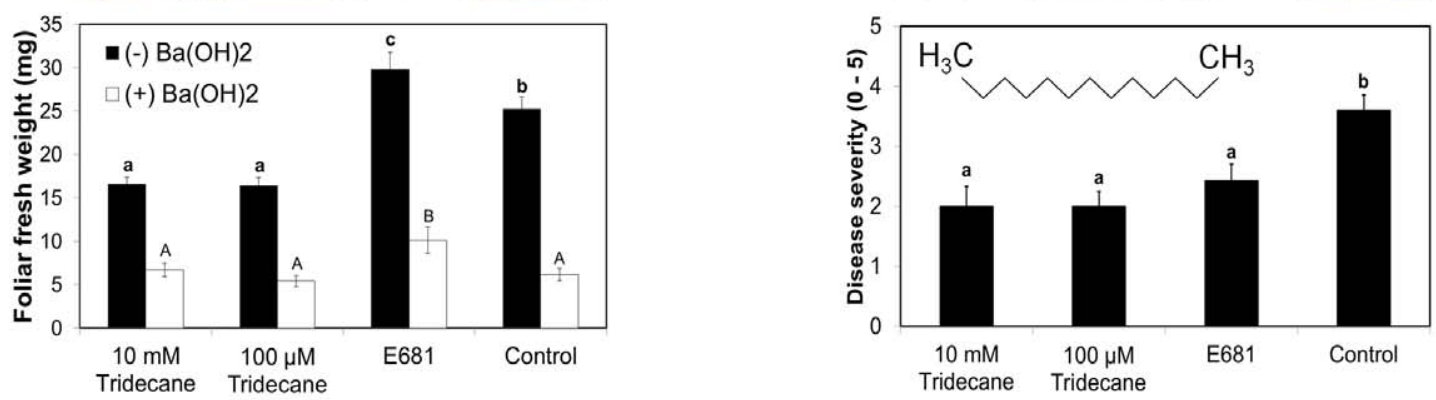

\section{After C13 VOC treatment}

\section{After pathogen challenge}
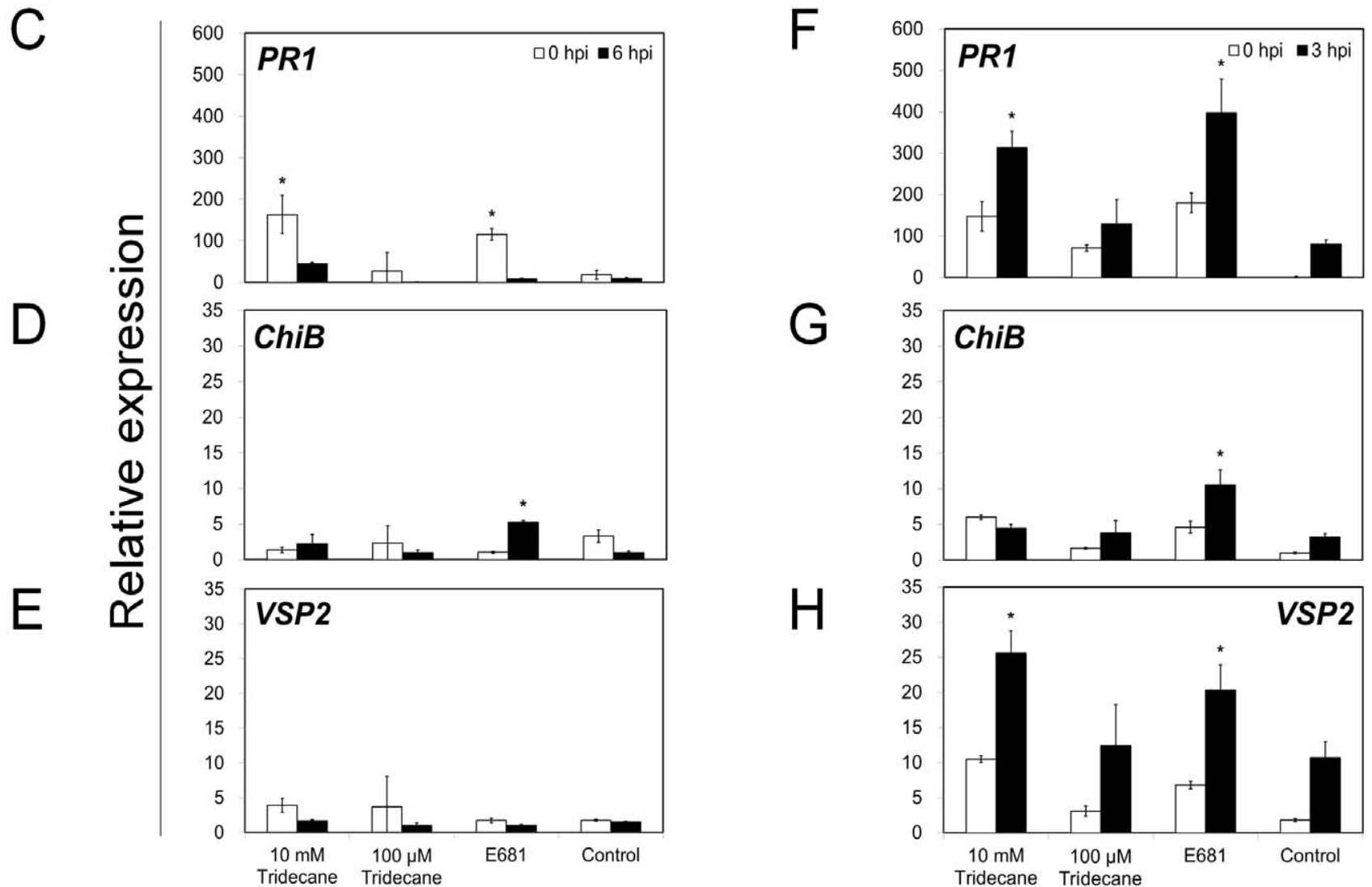

Figure 3. Induced systemic resistance and priming of defense-related genes by tridecane in Arabidopsis. A) Effect of tridecane on Arabidopsis growth. Plants were exposed to $10 \mathrm{mM}$ and $100 \mu \mathrm{M}$ tridecane, strain E681, and water for 2 weeks in presence (black bar) and absence of $\mathrm{Ba}(\mathrm{OH})_{2}$ (white bar). The photograph shows effect of $\mathrm{CO}_{2}$ on Arabidopsis growth treatments with $10 \mathrm{mM}$ and $100 \mu \mathrm{M}$ tridecane, strain E681, and water by the addition of $\mathrm{Ba}(\mathrm{OH})_{2}$ for trapping $\mathrm{CO}_{2}$ that precipitated as $\mathrm{BaCO}_{3}$. B) Induced systemic resistance against $P$. syringae pv. maculicola ES4326 elicited by strain E681 and $10 \mathrm{mM}$ and $100 \mu \mathrm{M}$ tridecane using the I-plate system. Disease severity $(0=$ no symptom, $5=$ severe chlorosis) was recorded seven days after pathogen challenge at $10^{8} \mathrm{cfu} / \mathrm{ml}$. Inset picture indicates chemical structure of tridecane. Gene expression levels of $P R 1 \mathrm{for}$ 
salicylic acid signaling (C and F), ChiB for ET signaling (D and G), and VSP2 for jasmonic acid signaling (E and $H)$, as determined by quantitative reverse transcriptase (qRT)-PCR after tridecane emission (C, D, and E) at 0 and 6 hour post-inoculation (hpi) and after pathogen challenge for detecting defense priming $(\mathrm{F}, \mathrm{G}$, and $\mathrm{H})$. The expression ratio $(\mathrm{C}-\mathrm{H})$, a ratio of the expression in the strain $\mathrm{E} 681$ or tridecane-inoculated treatment relative to expression of Actin gene, is shown as the mean \pm SEM. Different letters indicate significant differences between treatments (A and B) according to least significant difference at $P=0.05$.

doi:10.1371/journal.pone.0048744.g003

a blend of 30 VOCs, tridecane was found to elicit ISR against $P$. syringae pv. maculicola strain ES4326. Interestingly, tridecane has a negative effect on plant growth promotion (Fig. 3), indicating that different VOCs from bacteria play a role in plant growth promotion and ISR in plants. The qRT-PCR results indicated that tridecane emitted from strain E681 may elicit a plant defense mechanism via SA and or JA signaling pathways (Figs. 3F, G, and $\mathrm{H})$. For unequivocal proof of the involvement of respective defense signaling pathways, other signaling mutant lines of Arabidopsis need to be assessed in response to VOCs emission. Further studies are needed to evaluate results between decreases in disease severity following exposure to other VOCs like decane and undecane and priming of candidate defense genes (Figs. 4E, F, and G).

Plants may perceive diverse VOCs with similar structures at a given threshold level and prime diverse unknown downstream signaling pathways related to plant defense. In addition to ISR response, bacterial volatiles emitted from strain GB03 were recently reported to elicit an abiotic stress tolerance to salt stress, depending on activity of high-affinity $\mathrm{K}^{+}$transporter 1 (HKT1), which manipulates $\mathrm{Na}^{++}$homeostasis in the plant root system [27]. Similarly, application of Pseudomonas chlororaphis O6 to the root elicited ISR to biotic and abiotic stresses via volatile emission. Intriguingly, 2,3-butanediol, produced by $P$. chlororaphis, mediated stomata closure and drought resistance in Arabidopsis in an Aba-1and OST-1 kinase-dependent manner [28]. It is noteworthy that certain concentrations of a long chain hydrocarbon provide ISR against $P$. syringae, which suggests that the hydrocarbon is utilized as a biochemical trigger of induced systemic tolerance against abiotic stresses as well as induced resistance for managing plant diseases [29]. Finally, results presented herein provide evidence that strain E681 emits a long chain C13 volatile that can trigger a stronger ISR response than 2,3-butanediol or acetoin, and suggesting for the presence of other unidentified molecules that have yet to be identified and examined in large-scale field experiments.

\section{Conclusion}

Overall, the results provide new evidence that a C13 hydrocarbon, tridecane, emitted from Paenibacillus polymyxa, can promote plant growth via ET-dependent signaling pathway and can induce systemic resistance by priming of plant defense-related genes. In addition, this study provides new insight into the role of a species-specific long-chain bacterial volatile as a trigger of both growth promotion and defense in planta. The observed variation in volatile profiles among various PGPR strains suggests that a diverse VOC metabolism exists among PGPR and supports the idea that VOCs can serve as taxonomic markers in microbial systems [30]. Coupling these differential VOG profiles from different PGPR strains with the levels of gene transcription could prove useful for probing biosynthetic pathways leading to tridecane production in $P$. polymyxa.

\section{Materials and Methods}

\section{Bacteria and plant preparation}

PGPR strains Pseudomonas fluorescens 89B-61, B. amyloliqefaciens IN937a, Bacillus subtilis GB03, and Paenibacillus polymyxa E681 were streaked onto tryptic soy agar (TSA, Difco Laboratories, Detroit, MI, USA) plates and incubated for 24 hours in darkness at $28^{\circ} \mathrm{C}$. Strain E681 was previously isolated from the roots of winter barley in the southern part of Korea. For long-term storage, bacterial cultures were maintained at $-80^{\circ} \mathrm{C}$ in tryptic soy broth (TSB) (Difco Laboratories, Detroit, MI, USA) that contained $20 \%$ glycerol. Arabidopsis thaliana ecotype Columbia (Col-0) plants were prepared as described previously $[2,9,10]$. Foliar fresh weight was used as a measure of the growth parameter for plant growth promotion in A. thaliana ecotype Col-0. All chemicals including decane, undecane, dodecane, and tridecane were purchased from Sigma Aldrich.

\section{Assessment of plant growth promotion by bacterial volatiles}

In a preliminary experiment, the capacity of strains GB03, 89B61, and E681 to promote growth of wild type and mutant Arabidopsis plants was assessed using the previously described Iplate system $[9,10]$. To test the effect of bacterial volatiles on growth and ISR at different distances from the bacterial inoculation site, a 24-well microtitre plate system was developed. An Arabidopsis seedling was placed into each well, which contained $1 \mathrm{ml}$ of half-strength MS medium. The two wells of the first row were then inoculated with a bacterial suspension at $10^{8-9}$ colony forming units (cfu) per $\mathrm{ml}$ as shown in Fig. 1A to avoid physical contact between bacterial inoculation and plant. To assess the capacity of bacterial VOGs to promote plant growth, the total leaf surface area $\left(\mathrm{cm}^{2}\right)$ of each seedling growing $2,4,6,8$, and $10 \mathrm{~cm}$ from the bacterial inoculation site was measured two weeks after bacteria inoculation.

To exclude $\mathrm{CO}_{2}$ effect, $5 \mathrm{~mL}$ of $0.3 \mathrm{~N} \mathrm{Ba}(\mathrm{OH})_{2}$ was applied on one part of a 4-part divided Petri dish [19]. At 2-weeks after cultivation of plants in the presence of $0.3 \mathrm{~N} \mathrm{Ba}(\mathrm{OH})_{2}$, fresh weights of each aerial part of plants were measured. The mean value of plant fresh weight was compared with the mean fresh weight of plants cultivated without $\mathrm{Ba}(\mathrm{OH})_{2}$ (Fig. 3A).

\section{Assessment of induced systemic resistance by bacterial volatiles}

To determine if exposure of Arabidopsis seedlings to bacterial volatiles elicited ISR against Pseudomonas syringae pv. maculicola ES4326, we developed a 24-well microtitre-based disease assay system (Fig. 1A). The 24-multimicrotitre plate of bacterial suspensions of PGPR strains B. subtilis GB03 and P. polymyxa E681 at $\mathrm{OD}_{600}=1\left(10^{8-9} \mathrm{cfu} / \mathrm{ml}\right)$ was inoculated in an empty well (without plant). For assessing ISR by bacterial volatile and its derivatives, the I-plate system was employed. After application of $30 \mu \mathrm{l}$ of $10 \mathrm{mM}$ and $100 \mu \mathrm{M}$ decane, undecane, and dodecane, the I-plate was tightly sealed with parafilm. Seven days after inoculation with PGPR or VOCs, $2.5 \mathrm{ml}$ of a bacterial suspension $\left(\right.$ at $\mathrm{OD}_{600}=1$ ) of $P$. syringae pv. maculicola ES4326 grown on King's B medium was added to each well. A whole seedling in each well was then soaked in the bacterial suspension for $5 \mathrm{~min}$, and the suspension was removed. The plant was rinsed with sterile distilled water three times. The 24-multimicroliter plate with challenged Arabidopsis seedlings was then placed in a growth chamber that was maintained at $21^{\circ} \mathrm{C}$ in $12 / 12$ day and night 
A

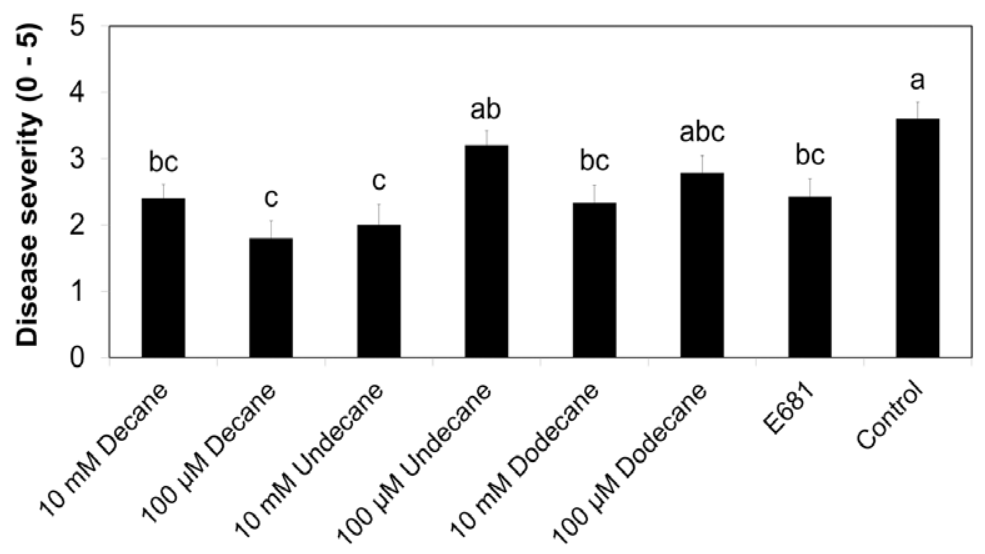

After C10 - C12 VOC treatment

After pathogen challenge

B<smiles>[3H]</smiles>

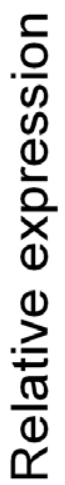

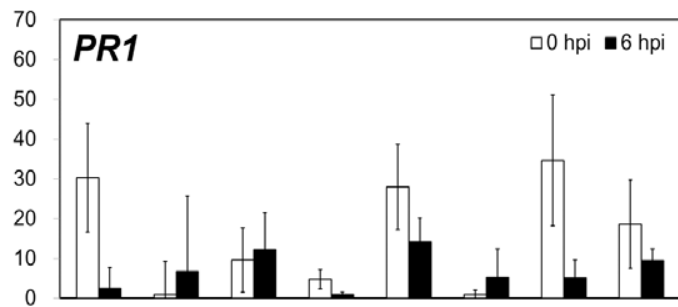

D

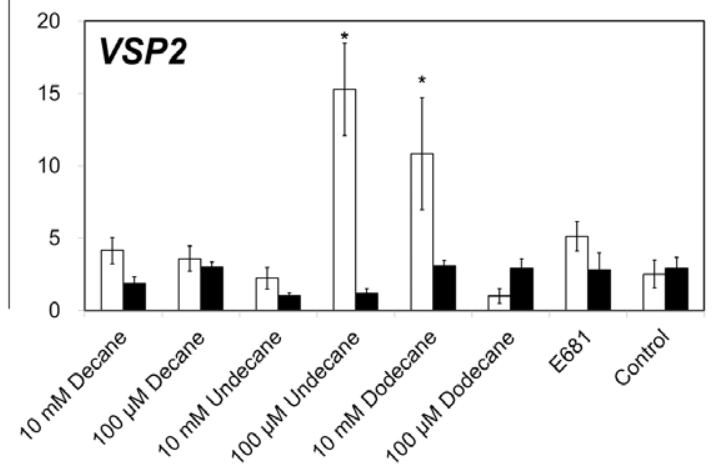

E

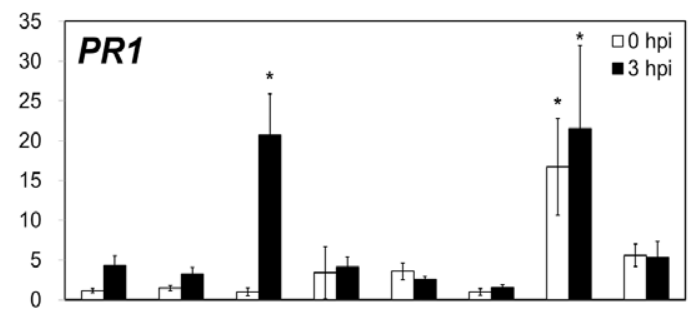

$E$

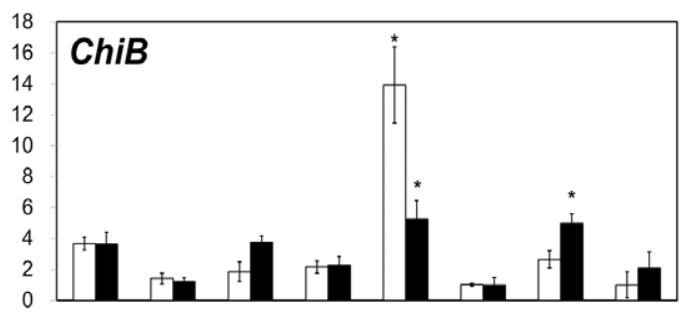

G

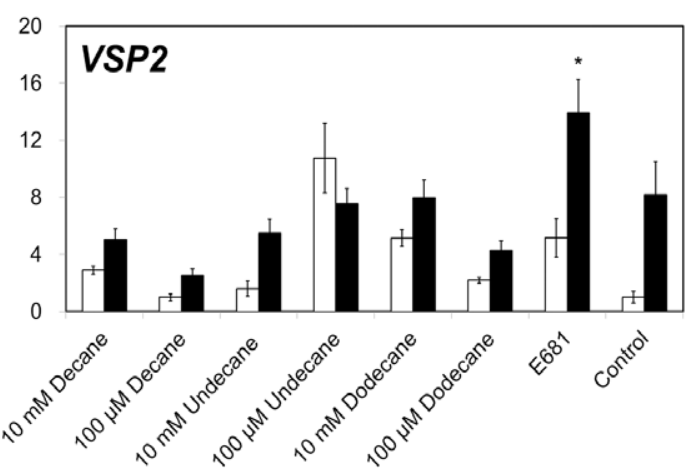

Figure 4. Induced resistance and priming of defense-related genes by long chain VOCs. A)Induced systemic resistance against $P$. syringae pv. maculicola ES4326 elicited by strain E681 and $10 \mathrm{mM}$ and $100 \mu \mathrm{M}$ of decane, undecane, and dodecane using the I-plate system. Disease severity $\left(0=\right.$ no symptom, $5=$ severe chlorosis) was recorded seven days after pathogen challenge at $10^{8} \mathrm{cfu} / \mathrm{ml}$. Gene expression levels of $P R 1 \mathrm{for}$ salicylic 
acid signaling ( $\mathrm{B}$ and $\mathrm{E})$, ChiB for ET signaling ( $\mathrm{C}$ and $\mathrm{F}$ ), and VSP2 for jasmonic acid signaling ( $\mathrm{D}$ and $\mathrm{G})$, as determined by quantitative reverse transcriptase (qRT)-PCR after tridecane emission (B, C, and D) at 0 and 6 hour post-inoculation (hpi) and after pathogen challenge for detecting defense priming $(E, F$, and $G)$. The expression ratio $(B-G)$, a ratio of the expression in the strain $E 681$ or tridecane treatment relative to water-treated control, is shown as the mean \pm SEM. Different letters indicate significant differences between treatments $(A)$ according to least significant difference at $P=0.05$.

doi:10.1371/journal.pone.0048744.g004

condition. Disease severity was measured four to seven days after pathogen challenge.

\section{Analysis of bacterial volatiles}

Bacillus subtilis strain GB03, B. amyloliqefaciens IN937a, P. polymyxa strain E681, and $P$. fluorescens strain 89B61 were grown in $20 \mathrm{ml}$ vials on MS medium containing $1.5 \%(\mathrm{w} / \mathrm{v})$ agar, $1.5 \%(\mathrm{w} / \mathrm{v})$ sucrose, and $0.4 \%(\mathrm{w} / \mathrm{v}) \mathrm{TSA}$ for $24 \mathrm{~h}$ at $37^{\circ} \mathrm{C}$ before volatiles were collected. Vials were sealed with a steel crimp cap fitted with a Teflon/silicon septum that was previously conditioned at $100^{\circ} \mathrm{C}$ for 30 minutes. (Z)-3-Hexenyl acetate, which is absent from bacterial cultures, was used as an internal standard (IS) and was injected at a concentration of $1 \mu \mathrm{g}$ per vial. Solid-phase microextraction (SPME) and gas chromatography-mass spectrometry (GC-MS) analysis were performed as previously described [18]. Briefly, vials containing samples were placed in a heating block (Gerstel Multi Purpose Sampler MPS 2, Baltimore, MD) at $50^{\circ} \mathrm{C}$ with a SPME fiber (stable flexdivinylbenzene/carboxen/ PDMS (DCP, 50/30 $\mu \mathrm{m}$ )) inserted into the headspace above the bacterial sample. Adsorption was timed for 30 minutes, and fibers were desorbed at $210^{\circ} \mathrm{C}$ for $1 \mathrm{~min}$ in the injection port of an $\mathrm{HP}$ 5890A GC/MS (Hewlett-Packard, Palo Alto, CA) with a DB-5 column (60 m, $0.25 \mathrm{~mm}$ i.d., $0.25 \mu \mathrm{m}$ film thickness) (J\&W Scientific, Folsom, CA). The HP quadrupole mass spectrometer was operated in the electron ionization mode at $70 \mathrm{eV}$, a source temperature of $200^{\circ} \mathrm{C}$, quadrupole temperature of $150^{\circ} \mathrm{C}$, with a continuous scan from m/z 40 to 500 . Positive identification of each chemical constituent was performed by comparison of its retention time and mass spectrum with that of authentic standard (when available). Tentatively identified compounds were uniquely identified on the basis of EPA/NIH database. Peaks were quantified by selected abundant fragments $(\mathrm{m} / \mathrm{z})$ to overcome the problem of co-eluted compounds [18]. Samples were run in triplicate, and integrated areas were normalized on (Z)-3-hexenyl acetate and averaged. Fourteen compounds were quantified using calibration curves of authentic standards. Quantification of volatiles' components was carried out with response factors (RFs). RFs and calibration curves were determined by diluting standards in water at four concentrations $(0.1,1,10$, and $100 \mu \mathrm{g} /$ $\mathrm{ml}$ ) as described by Farag et al. [18].

\section{Quantitative Reverse Transcriptase (qRT)-polymer chain reaction}

Total RNA was isolated from inoculated 14-day-old leaf tissues according to the protocol of Yang et al [29]. The purified total RNA was treated with $1 \mathrm{U}$ of RNase-free DNase (Promega, USA) for 10 minutes $(\mathrm{min})$ at $37^{\circ} \mathrm{C}$ and then subjected to a second round of purification using the TRI reagent. First-strand cDNA synthesis was carried out with $2 \mu \mathrm{g}$ of DNase-treated total RNA, oligo dT primers, and Moloney murine leukemia virus reverse transcriptase (MMLV-

\section{References}

1. Kloepper J, Metting F Jr. (1992) Plant growth-promoting rhizobacteria as biological control agents. Soil microbial ecology: applications in agricultural and environmental management: 255-274.

2. Ryu CM, Murphy JF, Mysore KS, Kloepper JW (2004) Plant growth-promoting rhizobacteria systemically protect Arabidopsis thaliana against Cucumber mosaic virus
RT; Invitrogen, USA). Expression of the candidate gene was analyzed using the following primers: 5'-TTCGACAACGAGGCACGAGG AG-3' (PR1_F), 5'-CCAGACAAGTCACGGCTACCG-3' (PR1_R); 5'-CGCTAAAGAACGACACGGTCAA-3' (VSP2_F), 5'-TCAAT CCGGAGCTCTATGATGTTT-3' (VSP2_R). AGI codes were PR1 (AT2G14610), VSP2 (AT5G24770), CHIB (AT3G12500), and AtACT2 (AT3G18780) as a control to ensure that equal amounts of RNA were analyzed in each experiment. AtActin was also assayed using the primers 5'-GTTAGCAACTGGGATGATATGG- and 5'-CAGCACGAATCGTGATGACTTGCGC-3'. Candidate priming genes were amplified from $100 \mathrm{ng}$ of cDNA by PCR using an annealing temperature of $60^{\circ} \mathrm{C}$. Q-RT-PCR was carried out using a Chromo4 real-time PCR system (Bio-Rad). Reaction mixtures $(10 \mu \mathrm{l})$ contained $5 \mu$ of $2 \times$ Brilliant SYBR Green QPCR master mix (Bio-Rad), cDNA, and 1 pmole of each primer. The thermocycle parameters were as follows: initial polymerase activation for $10 \mathrm{~min}$ at $95^{\circ} \mathrm{C}$, and then 40 cycles of 30 seconds (s) at $95^{\circ} \mathrm{C}, 30 \mathrm{~s}$ at $60^{\circ} \mathrm{C}$, and $30 \mathrm{~s}$ at $72^{\circ} \mathrm{C}$. Conditions were determined by comparing the threshold values in a series of dilutions of the RT product, followed by a non-RT template control and a non-template control for each primer pair. Relative RNA levels were calibrated and normalized to the level of AtAct2 mRNA.

\section{Statistical Analysis}

Analysis of variance for experimental data sets was performed using JMP software version 4.0 (SAS Institute Inc., Cary, NG). Significant treatment effects were determined based on the magnitude of the $F$ value $(P=0.05)$. When a significant $F$ test was obtained for treatments, separation of means was accomplished by Fisher's protected least significant difference (LSD) at $P=0.05$. Bioassays were conducted at least twice, with eight replicates per treatment and one seedling per replicate. For VOC analyses, four replicates per bacterial culture measured were performed.

\section{Supporting Information}

Figure S1 GUS activity in Arabidopsis plants transformed with ProPR-1::GUS or PDF1.2::GUS that were exposed to VOGs released from $P$. polymyxa $\mathbf{E 6 8 1}$ and $B$. subtilsis GB03. Induction of $P R 1$ and $P D F 1.2$ promoters fused with GUS by $P$. polymyxa E681 and $B$. subtilis GB03. Different letters (a, b for $P R-1 a$; x, y for PDF1.2) indicate significant differences between treatments within each Arabidopsis line, according to least significant difference at $P=0.05$. The error bars indicate S.E.M. (TIF)

\section{Author Contributions}

Conceived and designed the experiments: CMR JWK. Performed the experiments: BL HBP SHL CMR MAF. Analyzed the data: BL CMR MAF. Wrote the paper: GMR JWK MAF.

by a salicylic acid and NPR1-independent and jasmonic acid-dependent signaling pathway. Plant J 39: 381-392.

3. Ryu CM, Kim J, Choi O, Kim SH, Park CS (2006) Improvement of biological control capacity of Paenibacillus polymyxa E681 by seed pelleting on sesame. Biol Control 39: 282-289. 
4. Van Loon L, Bakker P, Pieterse C (1998) Systemic resistance induced by rhizosphere bacteria. Annu Rev Phytopathol 36: 453-483.

5. Kloepper JW, Ryu CM, Zhang S (2004) Induced systemic resistance and promotion of plant growth by Bacillus spp. Phytopathology 94: 1259-1266.

6. Glick BR (1995) The enhancement of plant growth by free-living bacteria. Can J Microbial 4: 109-117.

7. Lucy M, Reed E, Glick BR (2004) Applications of free living plant growthpromoting rhizobacteria. Anton Leeuw 86: 1-25.

8. Press C, Loper J, Kloepper J (2001) Role of iron in rhizobacteria-mediated induced systemic resistance of cucumber. Phytopathology 91: 593-598.

9. Ryu CM, Farag MA, Hu CH, Reddy MS, Kloepper JW, et al. (2004) Bacterial volatiles induce systemic resistance in Arabidopsis. Plant Physiol 134: 1017-1026.

10. Ryu CM, Farag MA, Hu CH, Reddy MS, Wei HX, et al. (2003) Bacterial volatiles promote growth in Arabidopsis. Proc Natl Acad Sci U S A 100: 49274932 .

11. Zhang H, Kim MS, Krishnamachari V, Payton P, Sun Y, et al. (2007) Rhizobacterial volatile emissions regulate auxin homeostasis and cell expansion in Arabidopsis. Planta 226: 839-851.

12. Ryu CH, Kim J, Choi O, Park SY, Park SH, et al. (2005) Nature of a rootassociated Paenibacillus polymyxa from field-grown winter barley in Korea. J Microbiol Biotechnol 15: 984-991.

13. Ryu CM, Hu CH, Locy RD, KloepperJW (2005) Study of mechanisms for plant growth promotion elicited by rhizobacteria in Arabidopsis thaliana. Plant Soil 268 : 285-292.

14. Lebuhn M, Heulin T, Hartmann A (1997) Production of auxin and other indolic and phenolic compounds by Paenibacillus polymyxa strains isolated from different proximity to plant roots. FEMS Microbiol Ecol 22: 325-334.

15. Nakashimada Y, Marwoto B, Kashiwamura T, Kakizono T, Nishio N (2000) Enhanced 2,3-butanediol production by addition of acetic acid in Paenibacillus polymyxa. J Biosci Bioeng 90: 661-664.

16. Timmusk S, Nicander B, Granhall U, Tillberg E (1999) Cytokinin production by Paenibacillus polymyxa. Soil Biol Biochem 31: 1847-1852.

17. Kim JF, Jeong H, Park SY, Kim SB, Park YK, et al. (2010) Genome sequence of the polymyxin-producing plant-probiotic rhizobacterium Paenibacillus polymyxa E681. J Bacteriol 192: 6103-6104.
18. Farag MA, Ryu CM, Sumner LW, Pare PW (2006) GC-MS SPME profiling of rhizobacterial volatiles reveals prospective inducers of growth promotion and induced systemic resistance in plants. Phytochemistry 67: 2262-2268.

19. Kai M, Piechulla B (2009) Plant growth promotion due to rhizobacterial volatiles-an effect of $\mathrm{CO}_{2}$ ? FEBS Lett 583: 3473-3477.

20. Kwon YS, Ryu CM, Lee S, Park HB, Han KS, et al. (2010) Proteome analysis of Arabidopsis seedlings exposed to bacterial volatiles. Planta 232: 1355-1370.

21. Han SH, Lee SJ, Moon JH, Park KH, Yang KY, et al. (2006) GacS-dependent production of $2 \mathrm{R}$, 3R-butanediol by Pseudomonas chlororaphis $\mathrm{O} 6$ is a major determinant for eliciting systemic resistance against Erwinia carotovora but not against Pseudomonas syringae pv. tabaci in tobacco. Mol Plant Microbe Interact 19: 924-930.

22. Tellez MR, Schrader KK, Kobaisy M (2001) Volatile components of the cyanobacterium Oscillatoria peromata (Skuja). J Agric Food Chem 49: 5989-5992.

23. Blum MS, Traynham JG, Chidester JB, Boggus JD (1960) n-Tridecane and trans-2-Heptenal in Scent Gland of the Rice Stink Bug Oebalus pugnax (F.). Science 132: 1480-1481.

24. Fucarino A, Millar JG, McElfresh JS, Colazza S (2004) Chemical and physical signals mediating conspecific and heterospecific aggregation behavior of first instar stink bugs. J Chem Ecol 30: 1257-1269.

25. Krall BS, Bartelt RJ, Lewis CJ, Whitman DW (1999) Chemical defense in the stink bug Cosmopepla bimaculata. J Chem Ecol 25: 2477-2494.

26. Todd JW (1989) Ecology and behavior of Nezara viridula. Annu Rev Entomol 34: 273-292.

27. Zhang H, Kim MS, Sun Y, Dowd SE, Shi H, et al. (2008) Soil bacteria confer plant salt tolerance by tissue-specific regulation of the sodium transporter HKT1. Mol Plant Microbe Interact 21: 737-744.

28. Cho SM, Kang BR, Han SH, Anderson AJ, Park JY, et al (2008) 2R,3Rbutanediol, a bacterial volatile produced by Pseudomonas chlororaphis O6, is involved in induction of systemic tolerance to drought in Arabidopsis thaliana. Mol Plant Microbe Interact 21: 1067-1075.

29. Yang J, Kloepper JW, Ryu CM (2009) Rhizosphere bacteria help plants tolerate abiotic stress. Trends Plant Sci 14: 1-4.

30. Scholler CE, Gurtler H, Pedersen R, Molin S, Wilkins K (2002) Volatile metabolites from actinomycetes. J Agric Food Chem 50: 2615-2621. 